more sophisticated than those of the Russian, for example, delays in the IMF loan tranches ... indeed, no military intervention is needed if the road to capital is open" (45). The book hardly furnishes sufficient evidence for such statements to be taken seriously. At the same time, the narrative too often triggers Karl Popper's (1963) critique of the twentieth-century extensions of Marxism as being essentially non-falsifiable.

A brief consideration of cases outside of Ukraine would have been illuminating. Ukraine's neighbors Belarus and Moldova, for example, have approached the "transition" quite differently from Kyiv. Are there any lessons to draw here for evaluating Ukraine's "neoliberal kleptocracy" (208) as the putative product of transnationalizing capital?

Methodology aside, there is a want of dialogue with scholars outside of the Marxist tradition (strictly speaking) in comparative political economy, which is regrettable as such accounts often resonate with the book's key themes, offering potential for deeper insights. Henry Hale's work on patronal politics (2014), for example, provides theoretical tools to understand the simulation of democracy by domestic elites in Ukraine. Juliet Johnson's (2016) volume points to the transnational central banking community as a route for the neoliberalization of the post-Soviet space. My own work on agent predation and stakeholder alliances in Ukraine and Russia (2015) offers a conceptual framework for understanding kleptocracies and the defensive mechanisms available to labor and small businesses. It may prove fruitful for these and other dialogues with fellow comparativists to occur in the future.

Overall, Yuliya Yurchenko has written an impressive book that readers interested in historical materialism and Ukraine will find indispensable.

STANISLAV MARKUS

Darla Moore School of Business, University of South Carolina

\title{
The Near Abroad Toronto: Socialist Eastern Europe and Soviet Patriotism in Ukraine, 1956-1985. By Zbigniew Wojnowski. Toronto: University of Toronto Press, 2017. xiii, 317 pp. Notes. Bibliography. Index. Maps. Illustrations. \$70.00, hard bound.
}

doi: 10.1017/slr.2019.133

During the Cold War, the depiction of Ukraine as a disenfranchised, occupied periphery of a "Muscovite" empire was a common rhetorical figure in Ukrainian émigré politics. Over the past decade this imagery has become part of official Ukrainian memory politics: in January 2018, the Director of the Ukrainian Institute of National Memory-a government agency tasked with the instrumentalization of history-declared that the Soviet period in Ukrainian history constituted an occupation.

The contrast to Zbigniew Wojnowski's approach could hardly be greater. Using Anthony D. Smith's theory, Wojnowski identifies Ukrainians as part of a Soviet "ethnic core." "To be Soviet meant to be Ukrainian and to be Ukrainian meant to be Soviet," (18) he argues. If some Ukrainian public intellectuals have sought to cast Ukrainians in the role of "colonial," "aboriginal" "Fridays"-and the relations between the two most important Soviet republics as a center-periphery relation, Wojnowski instead identifies Ukrainians as part of the center, arguing that "Ukrainian ethnic identities ... were a key source of legitimacy for the post-Stalinist Soviet state" (11). This identity, in turn, was articulated in opposition to the satellite states of the "near abroad": "Contrasting the core ethnic groups of the USSR with foreigners in the near abroad, citizens defined Sovietness as a composite East Slavic identity” (17). 
Soviet patriotism, the author argues, became a vehicle for Ukrainians to assert themselves within the system. Wojnowski identifies what he calls "conservative patriotism," built around this ethnic core, a joint history, and, in particular, the myths of the Great Patriotic War, which he juxtaposes to what he calls "reformist patriotism," a loyalty to the Soviet community based in a commitment that "the USSR should guide the satellite states through de-Stalinization" (25). The author notes that "anti-Soviet nationalism was a minority faith after the death of Stalin" (13), and that "radical voices were very isolated, even in the borderlands" (63).

The main focus is on what the author refers to as the Soviet Ukrainian "aspirational middle class" and how it "created spaces for citizens to cultivate social capital" (20). This group, Wojnowski argues, "saw Sovietness not as a foreign identity imposed by Moscow or an alternative to Ukrainian nation-building projects, but rather as a vehicle for promoting personal, regional, and Ukrainian interests cast in opposition to neighbors across the western border" (15).

These concepts were put to the test during the crises in the "near abroad" in 1956, 1969, and 1980-81. Wojnowski shows how, by appealing to Soviet patriotism, Ukrainians affirmed their loyalties and identity in opposition to an ethnic "other," affirming their proprietorship in the joint Soviet venture through what Wojnowski calls "staged patriotism": Poles and Czechs became indispensable "others" through which the Ukrainians could affirm their Soviet credentials and "to write themselves into the broader Soviet and Soviet Ukrainian community,"(191) thereby strengthening Soviet patriotism and contributing to the Sovietization of the western borderlands (205).

Chapters 1 and 2 analyze Soviet Ukrainian responses to the 1956 crises in Sovietsatellite relations, and the subsequent attempts to utilize cultural diplomacy to revive socialist internationalism. The events in Czechoslovakia in 1968 constituted another major challenge to the Soviet Ukrainian leadership; in Chapter 3, Wojnowski argues that the Prague spring ended the Thaw in the USSR. Chapters 4 and 5 survey how the intervention in Czechoslovakia dealt a major blow to the idea of internationalist friendship, from which it would never recover. In the 1970s and the early 80s, as the attraction of Soviet communist ideology declined, Wojnowski shows an increasing emphasis on ethno-national aspects of Soviet identity (138): "to be Soviet meant to be Ukrainian or Russian, and not Polish" (163). An epilogue links the past to the present, as the author identifies echoes of Soviet conservative patriotism in the "anti-Maidan" movement and the self-proclaimed "people's republics" in the east, whereas he identifies, in particular Viacheslav Chornovil and Rukh as products of the legacy of reformist patriotism. The far right rallies around the hagiography around Stepan Bandera.

The methodological challenges to reconstructing public opinion in a closed, oneparty republic are, as the author duly acknowledges, formidable. While he admits that "it is virtually impossible to access levels of 'genuine belief"' (184), the balanced use of sources-combining Soviet and Polish party and state reports with assessments by western analysts, the author is able to reconstruct, at least, the attitudes of a considerable section of Soviet Ukrainian society. Behind the filter of Soviet rhetoric-“a veneer of conformity," as he calls it (183)-Wojnowski restores voices, representing a spectrum of attitudes, often complex and ambiguous. The result is an original, balanced, and well-organized work, a significant contribution to our understanding of the late Soviet period and the field of Ukrainian studies.

Per ANDERs RudLing Lund University

(C) Association for Slavic, East European, and Eurasian Studies 2019. This is an Open Access article, distributed under the terms of the Creative Commons Attribution licence (http://creativecommons.org/licenses/by/4.0/), which permits unrestricted re-use, distribution, and reproduction in any medium, provided the original work is properly cited. 